Article

\title{
Temporal Changes in the Efficiency of Biochar- and Compost-Based Amendments on Copper Immobilization in Vineyard Soils
}

\author{
Christina Pump ${ }^{1}$, Katharina M. Keiblinger ${ }^{1, * \mathbb{D}}$, Elisabeth Scheiblauer ${ }^{1}$, Simone Johnen ${ }^{1}$, \\ Niklas J. Lehto ${ }^{2}$, Gerhard Soja ${ }^{3,4}$ (D) and Franz Zehetner ${ }^{1}$ \\ 1 Institute of Soil Research, University of Natural Resources and Life Sciences, A-1190 Vienna, Austria; \\ pumpchristina@gmail.com (C.P.); elisabeth.scheiblauer@gmx.at (E.S.); Simone-Johnen@gmx.de (S.J.); \\ franz.zehetner@boku.ac.at (F.Z.) \\ 2 Department of Soil and Physical Sciences, Faculty of Agriculture and Life Sciences, Lincoln University, \\ Christchurch 7647, New Zealand; niklas.lehto@lincoln.ac.nz \\ 3 AIT Austrian Institute of Technology GmbH, A-3430 Tulln, Austria; gerhard.soja@boku.ac.at \\ 4 Institute for Chemical and Energy Engineering, University of Natural Resources and Life Sciences, \\ A-1190 Vienna, Austria \\ * Correspondence: katharina.keiblinger@boku.ac.at; Tel.: +43-47654-91141
}

Received: 25 September 2019; Accepted: 20 November 2019; Published: 27 November 2019

\begin{abstract}
Copper $(\mathrm{Cu})$-based fungicides have been an important tool against disease in viticulture since the 19th century. However, their prolonged use can lead to $\mathrm{Cu}$ accumulation in the soil and negatively affect soil microbiology and plant growth. The application of biochar (BC)-based amendments is a promising mitigation strategy, due to BC's longevity in the soil and its potential to complex $\mathrm{Cu}$. This study investigated temporal changes in the efficiency of various compost- and BC-based amendments to immobilize $\mathrm{Cu}$ in a calcareous and a slightly acidic Austrian vineyard soil. The immobilization of both historically accumulated $\mathrm{Cu}$ and freshly spiked $\mathrm{Cu}\left(250 \mathrm{mg} \mathrm{kg}^{-1}\right)$ was studied. The soils were treated with six combinations of amendments containing compost and BC, with and without surface modification, as well as an additional lime treatment for the acidic soil. After treatment, the soils were incubated for 6 weeks and 3 years, after which the $0.01 \mathrm{M} \mathrm{CaCl}_{2}$-extractable $\mathrm{Cu}$ was measured. The amendments were not effective in reducing the mobility of the historically accumulated $\mathrm{Cu}$ in the calcareous soil, with pure compost doubling the soluble $\mathrm{Cu}$. Pure wood-chip BC was the only organic amendment that led to a reduction (by 20\%) of soluble Cu after 6 weeks in the acidic soil; however, after 3 years, the same amendment reduced soluble $\mathrm{Cu}$ by $40 \%$ and all other tested amendments were also effective in reducing the mobility of the historically accumulated $\mathrm{Cu}$. The lime treatment achieved the greatest reduction in $\mathrm{Cu}$ mobility (56\%). Freshly spiked $\mathrm{Cu}$ was strongly immobilized in both unamended soils, with $0.06 \%$ and $0.39 \%$ extractable after 6 weeks in the calcareous and slightly acidic soil, respectively. The amendments did not effectuate additional $\mathrm{Cu}$ immobilization in the calcareous soil, but in the acidic soil, the soluble $\mathrm{Cu}$ was further reduced to between $25 \%$ and $50 \%$ of the unamended control by the tested organic amendments and to $6 \%$ by the lime treatment after 6 weeks of incubation. Overall, the acidic soil exhibited a stronger response to the amendments than did the calcareous soil, suggesting the amendments' effect on the soil $\mathrm{pH}$ was an important factor for $\mathrm{Cu}$ immobilization in this study. These results show the importance of developing site-specific remediation strategies for $\mathrm{Cu}$ accumulation in agricultural soils.
\end{abstract}

Keywords: charcoal; compost; soil amendment; aging; fungicide; heavy metal; soil remediation 


\section{Introduction}

In viticulture, the application of copper $(\mathrm{Cu})$-based pesticides is commonly used to fight disease outbreak, such as downy mildew [1-3]. Copper is naturally derived from the soil parent material and is present at an average concentration of approximately $30 \mathrm{mg} \mathrm{kg}^{-1}$. However, the use of copper-based fungicides in agricultural soils has led to $\mathrm{Cu}$ concentrations ranging from 77 to $3200 \mathrm{mg} \mathrm{kg}^{-1}$ [3-6]. This can have negative repercussions on soil microbiology and plants [6-8].

Copper is typically present in soils either incorporated into minerals or adsorbed to inorganic and organic soil particles, with a very small fraction of the total as its divalent free ion form $\left(\mathrm{Cu}^{2+}\right)$ in solution $[3,9]$. The fraction of $\mathrm{Cu}$ in soil solution can readily exchange between solution and solid phases and may be considered potentially bioavailable, as most soil organisms take up the metal from the soil solution. Forthwith, this fraction shall be referred to as the 'soluble' fraction for simplicity. Although not all the $\mathrm{Cu}$ complexed with dissolved organic ligands may be biologically available, dissolved organic $\mathrm{Cu}$ complexes should still be taken into account when determining potential toxicity [10-12]. Cu complexes may also be more mobile in soils than uncomplexed species [13-15]. The dangers of $\mathrm{Cu}$ accumulation do not necessarily come from the threat of leaching, but rather from the increased risk of potential availability to plants and soil microbes [16-18].

Soil amendments such as biochar (BC) and compost have been found to be effective in reducing $\mathrm{Cu}$ toxicity as they can bind the metal into less bioavailable forms $[5,18]$. The reduction is more pronounced if the amendment has a high specific surface area and cation exchange capacity (CEC), and if it raises soil $\mathrm{pH}$ [19-24]. The use of these soil amendments can also promote the release of dissolved organic matter (DOM), which may facilitate the formation of soluble $\mathrm{Cu}-\mathrm{DOM}$ complexes and thus lead to increasing the metal's mobility [22,25-27]. Recent research suggests that activation processes, such as chemical oxidation, can be applied to further improve specific physiochemical properties of $B C$, such as increasing the amounts of surface functional groups that can bind trace metals [28-30].

Apart from oxidative activations, surface modifications with metals have also proven to be useful for increasing the sorption potential of biochar for environmental contaminants, including anions which pose a risk for surface water eutrophication [31-33]. Biochar's longevity in the soil makes it a useful tool in carbon sequestration, although the long-term impacts on $\mathrm{Cu}$ immobilization are not yet fully understood [34,35]. It may be that the initial positive 'priming effect' of BC is transient and may decline or even reverse into a negative effect over time [36-40]. Oxygen-containing surface functional groups increase in numbers as $\mathrm{BC}$ is oxidized, potentially causing the initially hydrophobic $\mathrm{BC}$ to become more hydrophilic [20,41-44], which may also change the BC's binding capacity for metals and, hence, metal bioavailability over time [5,45-47]. Compared to historically accumulated $\mathrm{Cu}$, freshly applied $\mathrm{Cu}$ may be more mobile in the soil as it has not yet been bound, leading to increased leaching and potentially also a greater impact of soil amendments $[48,49]$.

As $\mathrm{Cu}$-based pesticides are currently the most effective tool in fighting fungal disease in organic viticulture, long-term mitigation strategies are vital. However, information on the longer-term effects of BC- and compost-based amendments covering both historical and fresh $\mathrm{Cu}$ contamination is still scarce. The objective of this study was therefore to determine the longer-term effects of BCand compost-based amendments on soluble $\mathrm{Cu}$ concentrations in historically contaminated and freshly Cu-spiked vineyard soils. Two hypotheses were tested: (i) the amendments reduce soluble $\mathrm{Cu}$ concentrations due to modification of the $\mathrm{BC}$ surface, with a more pronounced effect in freshly $\mathrm{Cu}$-spiked soils, and (ii) the soils incubated with $\mathrm{BC}$ over a longer period immobilize $\mathrm{Cu}$ more strongly than soils where the incubation period is shorter.

\section{Materials and Methods}

\subsection{Experimental Setup}

Two Austrian vineyards soils were selected: a calcareous sandy loam from Rossatz (Wachau, Lower Austria) and a slightly acidic loam from Sankt Stefan (Western Styria), each with a history 
of $\mathrm{Cu}$-containing fungicide use, resulting in increased soil $\mathrm{Cu}$ concentrations. Topsoil $(0-10 \mathrm{~cm})$ was collected at various locations throughout the two vineyards and combined to one composite sample per vineyard. The samples were fully homogenized and sieved to $<2 \mathrm{~mm}$ while moist, prior to the incubation experiments and further analyses. An overview of basic soil properties is given in Table 1 .

Table 1. Soil properties of the two Austrian vineyard soils used in this study. Data from Soja et al. [50].

\begin{tabular}{|c|c|c|c|c|c|c|c|c|}
\hline & \multirow{2}{*}{$\underset{(1: 10)}{\mathrm{pH} \text { in } \mathrm{CaCl}_{2}}$} & Organic C & Sand & Silt & Clay & \multirow{2}{*}{$\begin{array}{c}\text { Total Cu } \\
\left(\mathrm{mg} \mathrm{kg}^{-1}\right)\end{array}$} & \multirow{2}{*}{$\begin{array}{c}\mathrm{eCEC}^{1} \\
\left(\mathrm{mmol}_{\mathrm{c}} \mathrm{kg}^{-1}\right)\end{array}$} & \multirow{2}{*}{$\mathrm{WHC}^{2}(\%)$} \\
\hline & & & $\%$ & & & & & \\
\hline Calcareous soil & 7.21 & 0.9 & 63 & 26 & 11 & 337 & 131 & 24.7 \\
\hline Acidic soil & 6.15 & 2.7 & 45 & 34 & 21 & 201 & 185 & 50.1 \\
\hline
\end{tabular}

Compost, derived from green garden waste, was obtained from a commercial compost plant in Pixendorf, Austria. It had a total $\mathrm{Cu}$ concentration of $40.4 \mathrm{mg} \mathrm{kg}^{-1}$ and a $\mathrm{pH}$ (in $\mathrm{CaCl}_{2}$ ) of 7.4. The compost was applied to the two soils at a rate of $1.5 \mathrm{wt} \%$ (corresponding to $40 \mathrm{t}$ dry matter ha ${ }^{-1}$ ) as a separate treatment and in combination with different BCs.

Biochar was produced from soft wood chips, mostly poplar, by the company Sonnenerde in Riedlingsdorf, Austria. It was carbonized by slow pyrolysis in a Pyreg reactor (PYREG GmbH, 56281 Dörth, Germany) at $480{ }^{\circ} \mathrm{C}$ and had a Cu concentration of $0.2 \mathrm{mg} \mathrm{kg}^{-1}$. Subsets of the $\mathrm{BC}$ were then modified through pre-treating with $\mathrm{H}_{2} \mathrm{O}_{2}$ and citric acid. These modifications were performed to enhance specific physiochemical properties with the intended outcome of increased $\mathrm{Cu}$ binding as compared to untreated wood $\mathrm{BC}$. To produce the $\mathrm{H}_{2} \mathrm{O}_{2}$-oxidized $\mathrm{BC}$, an equivalent of $1 \mathrm{~g}$ carbon of $<2 \mathrm{~mm}$ sieved wood $\mathrm{BC}$ was shaken with $70 \mathrm{~mL} 0.01 \mathrm{M} \mathrm{H}_{2} \mathrm{O}_{2}$ in a water bath at $80{ }^{\circ} \mathrm{C}$ for $48 \mathrm{~h}$. The resulting $\mathrm{BC}$ was washed four times in distilled water and dried at room temperature for two days [51]. The citric acid (CA) treatment followed the procedure of Zhu et al. [52]; $1 \mathrm{~g}$ of BC was mixed with $6.25 \mathrm{~mL}$ of $1 \mathrm{MCA}$ and dried at $50^{\circ} \mathrm{C}$ in a forced air oven for fourteen hours. In order to accelerate the thermochemical reaction between acid and wood $\mathrm{BC}$, the oven temperature was increased to $110^{\circ} \mathrm{C}$ for two hours. After cooling, the $\mathrm{BC}$ was washed four times with distilled water to remove an excess of CA and tested for unreacted CA with $0.1 \mathrm{M}$ lead (II) nitrate. The basic properties of the soil amendments are given in Table 2.

Table 2. Biochar and compost properties (Ameur et al., 2018 [40]; Soja et al., 2018 [50]).

\begin{tabular}{cccc}
\hline Parameter & Compost & Wood-BC & Citric-Acid Activated Wood-BC \\
\hline $\mathrm{pH}\left(\mathrm{CaCl}_{2}\right)$ & 7.4 & 8.5 & 2.7 \\
\hline $\mathrm{EC}\left[\mu \mathrm{S} \mathrm{cm}^{-1}\right]^{1}$ & 2160 & 392 & 1504 \\
\hline $\mathrm{CaCO}_{3}[\%(w / w)]$ & 7.99 & 4.02 & 0.19 \\
\hline $\mathrm{CEC}\left[\mathrm{mmol}_{\mathrm{c}} \mathrm{kg}^{-1}\right]$ & 708.8 & 55.7 & 135.1 \\
\hline $\mathrm{Cu}\left[\mathrm{mg} \mathrm{kg}^{-1}\right]$ & 40.4 & 0.2 & 0.1 \\
\hline $\mathrm{C}[\%(w / w)]$ & $22.1^{3}$ & 79.2 & 79.6 \\
\hline $\mathrm{N}[\%(w / w)]$ & $1.33^{3}$ & 0.44 & 0.42 \\
\hline $\mathrm{C} / \mathrm{N}^{2}$ & $10.6^{3}$ & 180 & 0 \\
\hline contact angle & - & 44.6 & 8.8 \\
\hline ash content & - & 23.2 & \\
\hline${ }^{1}$ solid: water ratio $=1: 10(w / v) ;{ }^{2}$ ratio based on weight $\%{ }^{3}$ values obtained by Cewe $\mathrm{GmbH}$.
\end{tabular}

The two sampled vineyard soils were subjected to five treatments, where either the compost or BC, or a combination of compost and treated or untreated BCs was applied to the two soils at equivalent rates (Table 3). The acidic soil was additionally treated with lime (in the form of $\mathrm{CaCO}_{3}$ ) as a separate treatment. For field applications, usually a combination of biochar and compost is recommended 
because compost supplements nutrient deficiencies of biochar. The ratio of compost:biochar of 1:3 was selected as a compromise between the demands of long-term C-sequestration (biochar), copper sorption (biochar), and nutrient supply (compost).

Table 3. Amendments tested in the incubation experiments.

\begin{tabular}{cccc}
\hline Amendment & Abbreviation & Application Rate (wt\%) & $\begin{array}{c}\text { Corresponding Field } \\
\text { Application Rate (t DM ha }\end{array}$ \\
\hline Control
\end{tabular}

The treated soils were then subjected to two batches of incubation experiments to test the extent to which the different soil amendments immobilize $\mathrm{Cu}$ changes over time. Prior to incubation, $30 \mathrm{~g}$ of each soil (dry matter equivalent weight) was added to $50 \mathrm{~mL}$ plastic Erlenmeyer flasks. In one batch, amendments were added to the soil at the rates given in Table 3 , after which they were incubated at $10^{\circ} \mathrm{C}$ for 6 weeks and 3 years, respectively. This was done to test the potential effects of the amendments and their changes over time on historically contaminated soils. In another batch, the amendments were added to the soils as before, after which the amended soils were spiked with $\mathrm{Cu}$ by adding $250 \mathrm{mg} \mathrm{kg}^{-1}$ in form of $\mathrm{CuSO}_{4}$ (aq) to increase their total concentrations and then incubated for 6 weeks and 3 years, as before. The flasks were covered with cotton wool to ensure gaseous exchange while preventing contamination or excessive loss of water. The moisture contents were maintained at $50 \%$ water holding capacity (WHC) by weighing each Erlenmeyer flask and adding MilliQ water in tri-weekly intervals. Each soil-amendment-incubation combination was replicated thrice.

\subsection{Extractable $\mathrm{Cu}$, Dissolved Organic Carbon (DOC), and $\mathrm{pH}$}

At the end of the incubation, the soils were air-dried and homogenized, after which the soluble fraction of $\mathrm{Cu}$ was extracted using the method described by Houba et al. [53]. Briefly, $3 \mathrm{~g}$ of soil was mixed with $30 \mathrm{~mL} 0.01 \mathrm{M} \mathrm{CaCl}_{2}$ solution in $50 \mathrm{~mL}$ centrifuge tubes. The tubes were transferred to a rotational shaker and shaken at room temperature for two hours and then centrifuged for ten minutes at $2000 \mathrm{rpm}$ (Rotanta $460 \mathrm{R}$, Hettich, Germany). The solutions were filtered through $0.45 \mu \mathrm{m}$ cellulose acetate membrane filters. An aliquot of the filtrate was acidified with three droplets of $65 \% \mathrm{HNO}_{3}$ (p.a.) for $\mathrm{Cu}$ analysis, and another (not acidified) aliquot was used to measure $\mathrm{pH}$ and extractable organic carbon.

The $\mathrm{Cu}$ concentration in the $\mathrm{CaCl}_{2}$ extracts was first measured using flame atomic absorption spectroscopy (AAS, Perkin Elmer). Where the concentrations were below the flame AAS limit of quantification ( $\left.50 \mu \mathrm{g} \mathrm{L}^{-1}\right)$, graphite furnace atomic absorption spectroscopy (GF-AAS, Perkin Elmer) and inductively coupled plasma-mass spectrometry (ICP-MS, Agilent 7700, Agilent Technologies, Santa Clara, CA) were used.

For determination of $\mathrm{CaCl}_{2}$-extractable organic carbon, used interchangeably with the term DOC in this paper, the UV absorbance at $254 \mathrm{~nm}$ was measured in BRANDplates ${ }^{\circledR}$ pureGradeTM 96-Well Microtiterplates in two replicates on a Multimode plate reader (EnSpire ${ }^{\circledR}$, Perkin Elmer), and the DOC was estimated following the regression equation developed by Brandstetter et al. [54]. The DOC concentrations of the $\mathrm{CaCl}_{2}$ extracts were measured in $\mathrm{mg} \mathrm{L}^{-1}$ and then converted to $\mathrm{mg} \mathrm{kg}^{-1}$ based on the soil:solution ratio $(1: 10)$ of the extracts. The $\mathrm{pH}$ values were measured using a $\mathrm{pH}$-meter (WTW, InoLab). 


\subsection{Data Evaluation and Statistical Analyses}

Statistical analyses were carried out using the program SPSS 22 (IBM). To determine differences between amendments, a one-way ANOVA was conducted, followed by Tukey's HSD post-hoc test. Welch's test was used to test for significant differences between incubation times. To determine the effect of each variable as well as the interaction between amendments and incubation, a two-way ANOVA was conducted. Significance was tested for $p<0.05$ in all cases.

\section{Results}

\subsection{Historically Contaminated Soils}

\subsubsection{Effects of Amendments and Incubation Time on $\mathrm{CaCl}_{2}$-Extractable $\mathrm{Cu}$}

In the calcareous soil, in the six-week incubation, none of the amendments achieved a significant reduction in the extractable $\mathrm{Cu}$ concentration (Figure 1a). In contrast, the compost and the compost + CA-act. BC amendments effectuated a significant $\mathrm{Cu}$ increase by $88 \%$ and $14 \%$, respectively. In the three-year incubation, the compost amendment again significantly increased soluble $\mathrm{Cu}$ by $43 \%$. However, this was contrasted by a significant $\mathrm{Cu}$ decrease of $21 \%$ in the BC amendment.
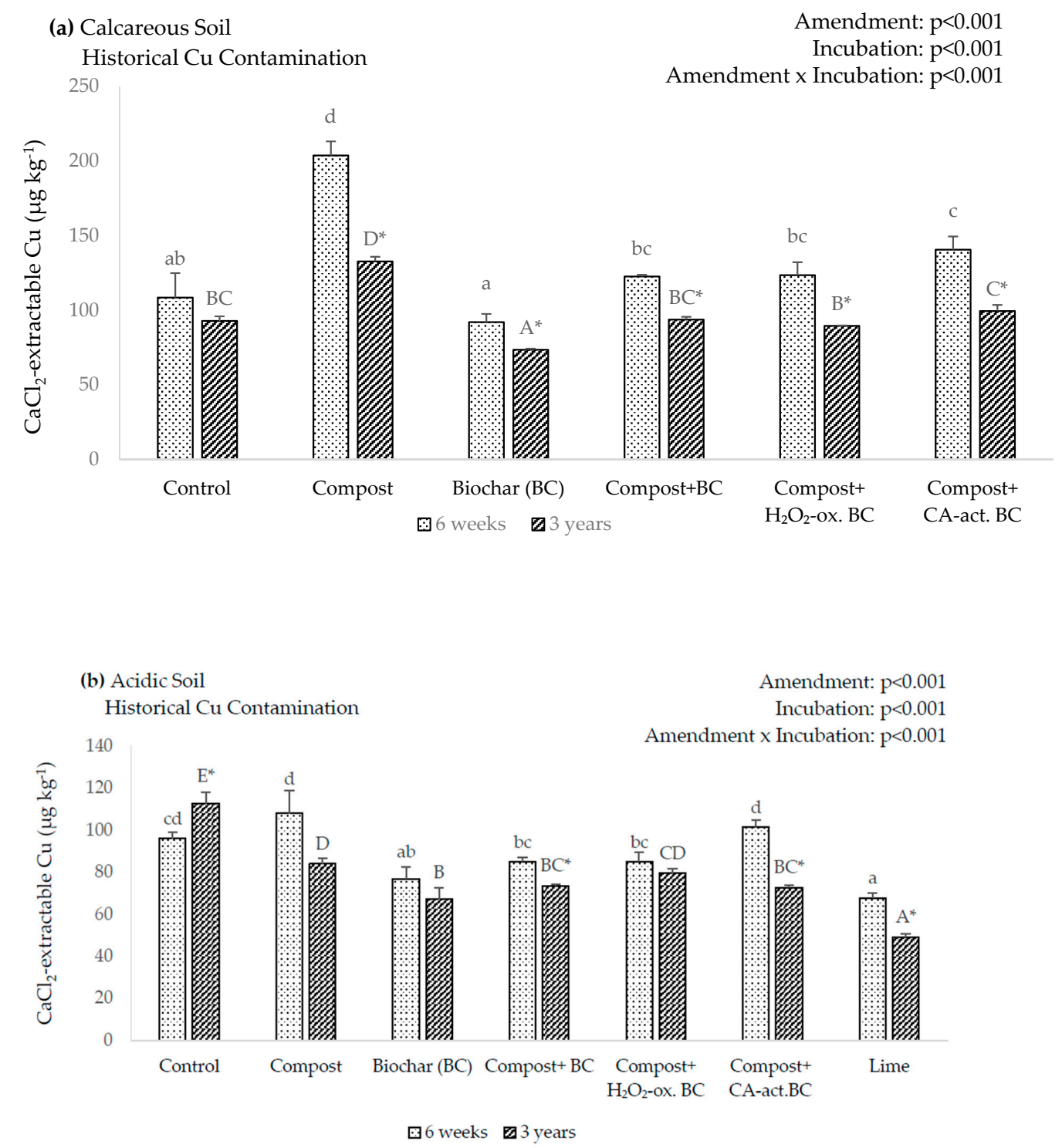

Figure 1. (a,b) $0.01 \mathrm{M} \mathrm{CaCl}_{2}$-extractable $\mathrm{Cu}$ after the incubation of the amendments in historically 
$\mathrm{Cu}$-contaminated soils. Lowercase letters indicate significant differences between amendments after 6 weeks of incubation, uppercase letters indicate significant differences between amendments after 3 years of incubation, asterisks indicate significant differences between incubation times $(p<0.05)$. Error bars indicate standard deviation, $n=3$.

In the acidic soil, the six-week incubation showed a significant $\mathrm{Cu}$ reduction in the $\mathrm{BC}$ and the lime amendments (Figure $1 \mathrm{~b}$ ). In these amendments, $\mathrm{CaCl}_{2}$-extractable $\mathrm{Cu}$ decreased by $20 \%$ and $30 \%$, respectively. In the three-year incubation, all amendments demonstrated a significant reduction in $\mathrm{CaCl}_{2}$-extractable $\mathrm{Cu}$. The largest reduction was in the lime amendment, with a decrease of $56 \%$, whereas compost had the smallest reduction of $25 \%$.

All amendments in the calcareous soil exhibited a significant decrease in $\mathrm{CaCl}_{2}$-extractable $\mathrm{Cu}$ from the six-week to the three-year incubation, with the exception of the control (Figure 1a). The largest reduction was in the compost amendment, which decreased by $35 \%$. In comparison, the BC demonstrated the smallest change, decreasing by $20 \%$.

In the acidic soil, some amendments showed a decrease of $\mathrm{CaCl}_{2}$-extractable $\mathrm{Cu}$ in the three-year incubation (Figure 1b). The exception to this was the control, which increased in the three-year incubation by $17 \%$, and the compost, $\mathrm{BC}$, and compost $+\mathrm{H}_{2} \mathrm{O}_{2}$-ox. $\mathrm{BC}$ showed no significant variations. Although the compost amendment did have a reduction of $22 \%$, it was not considered significant due to the large standard deviation. Of the significant decreases, compost + CA-act. BC showed the largest change, decreasing by $28 \%$.

\subsubsection{Effects of Amendments and Incubation Time on $\mathrm{pH}$ and Extractable Organic Carbon (DOC)}

The addition of the amendments had no significant impact on the $\mathrm{pH}$ of the calcareous soil, in the six-week incubation, and only impacted the BC amendment in the three-year incubation (Table 4). In the acidic soil, there was a significant increase in the $\mathrm{pH}$ of the compost and lime amendments, from 6.06 to 6.39 and 6.84, respectively, in the six-week incubation, whereas in the three-year incubation, there was no significant change in the $\mathrm{pH}$ level through the amendments.

Table 4. $\mathrm{pH}$ and DOC concentration after the incubation of the amendments in historically Cu-contaminated soils. Lowercase letters indicate significant differences between amendments after 6 weeks of incubation, uppercase letters indicate significant differences between amendments after 3 years of incubation, asterisks indicate significant differences between incubation times $(p<0.05)$. \pm values indicate standard deviation, $n=3$.

\begin{tabular}{|c|c|c|c|c|c|c|c|c|}
\hline & \multicolumn{4}{|c|}{$\mathrm{pH}\left(\right.$ in $\left.\mathrm{CaCl}_{2}\right)$} & \multicolumn{4}{|c|}{ DOC $\left(\mathrm{mg} \mathrm{kg}^{-1}\right)$} \\
\hline & \multicolumn{2}{|c|}{ Calcareous } & \multicolumn{2}{|c|}{ Acidic } & \multicolumn{2}{|c|}{ Calcareous } & \multicolumn{2}{|c|}{ Acidic } \\
\hline & 6 Weeks & 3 Years & 6 Weeks & 3 Years & 6 Weeks & 3 Years & 6 Weeks & 3 Years \\
\hline Control & $6.65( \pm 0.03)$ a & $6.06( \pm 0.36) \mathrm{A}$ & $6.06( \pm 0.16)$ a & $5.95( \pm 0.17) \mathrm{AB}$ & $27.3( \pm 3.1) \mathrm{ab}$ & $58.7( \pm 0.2) \mathrm{B}^{*}$ & $37.1( \pm 1.9)$ a & $54.0( \pm 2.9) \mathrm{A}^{*}$ \\
\hline Compost & $6.66( \pm 0.07)$ a & $6.37( \pm 0.12) A^{*}$ & $6.39( \pm 0.12) b$ & $6.23( \pm 0.07) \mathrm{AB}$ & $59.7( \pm 1.95) \mathrm{d}$ & $73.6( \pm 3.7) C^{*}$ & $66.0( \pm 3.4) \mathrm{d}$ & $70.1( \pm 1.7) \mathrm{B}$ \\
\hline $\mathrm{BC}$ & $6.61( \pm 0.22)$ a & $6.22( \pm 0.12) \mathrm{B}$ & $5.99( \pm 0.06)$ a & $5.99( \pm 0.24) \mathrm{AB}$ & $25.5( \pm 0.4)$ a & $50.4( \pm 5.5) \mathrm{A}^{*}$ & $34.8( \pm 0.2) \mathrm{a}$ & $47.9( \pm 5.2) \mathrm{A}^{*}$ \\
\hline Compost $+\mathrm{BC}$ & $6.64( \pm 0.28)$ a & $6.42( \pm 0.05) \mathrm{A}$ & $6.14( \pm 0.06) \mathrm{ab}$ & $5.99( \pm 0.23) \mathrm{AB}$ & $32.4( \pm 3.0) \mathrm{ab}$ & $57.6( \pm 1.3) \mathrm{AB}^{*}$ & $43.4( \pm 1.7) b$ & $54.7( \pm 1.5) \mathrm{A}^{*}$ \\
\hline $\begin{array}{c}\text { Compost }+ \\
\mathrm{H}_{2} \mathrm{O}_{2} \text {-ox. BC }\end{array}$ & $6.63( \pm 0.14) \mathrm{a}$ & $6.53( \pm 0.16) \mathrm{A}$ & $6.18( \pm 0.18) a b$ & $6.17( \pm 0.08) \mathrm{AB}$ & $34.2( \pm 2.1) b$ & $55.6( \pm 0.7) \mathrm{AB}^{*}$ & $44.7( \pm 2.0) \mathrm{b}$ & $54.1( \pm 1.1) \mathrm{A}^{*}$ \\
\hline $\begin{array}{l}\text { Compost + } \\
\text { CA-act. BC }\end{array}$ & $7.00( \pm 0.06) \mathrm{a}$ & $6.26( \pm 0.12) A^{*}$ & $6.26( \pm 0.01) a b$ & $5.84( \pm 0.10) \mathrm{A}^{*}$ & $49.2( \pm 5.6) \mathrm{c}$ & $61.8( \pm 2.0) \mathrm{B}^{*}$ & $52.4( \pm 1.1) \mathrm{c}$ & $51.4( \pm 1.7) \mathrm{A}$ \\
\hline \multirow[t]{2}{*}{ Lime } & & & $6.84( \pm 0.11) \mathrm{c}$ & $6.40( \pm 0.19) \mathrm{B}^{*}$ & & & $47.3( \pm 1.7) \mathrm{bc}$ & $70.5( \pm 1.3) \mathrm{B}^{*}$ \\
\hline & \multicolumn{2}{|c|}{$\begin{array}{l}\text { Amendment: n.s. } \\
\text { Incubation: } p<0.001 \\
\text { Amendment } \mathrm{x} \\
\text { Incubation: } p=0.034\end{array}$} & \multicolumn{2}{|c|}{$\begin{array}{l}\text { Amendment: } p<0.001 \\
\text { Incubation: } p<0.001 \\
\text { Amendment } \mathrm{x} \\
\text { Incubation: } \text { n.s. }\end{array}$} & \multicolumn{2}{|c|}{$\begin{array}{l}\text { Amendment: } p<0.001 \\
\text { Incubation: } p<0.001 \\
\text { Amendment } \mathrm{x} \\
\text { Incubation: } p<0.001\end{array}$} & \multicolumn{2}{|c|}{$\begin{array}{l}\text { Amendment: } p<0.001 \\
\text { Incubation: } p<0.001 \\
\text { Amendment } \mathrm{x} \\
\text { Incubation: } p<0.001\end{array}$} \\
\hline
\end{tabular}

In the calcareous soil, there was a decrease in $\mathrm{pH}$ in the compost and the compost + CA-act. $\mathrm{BC}$ amendments from the six-week incubation to the three-year incubation. The largest significant change was in the compost + CA-act. BC amendment. In the acidic soil, two amendments showed 
decreases in $\mathrm{pH}$ level from the six-week incubation to the three-year incubation, compost + CA-act. $\mathrm{BC}$ and lime.

The DOC increased significantly following the addition of the compost and the compost + CA-act. $\mathrm{BC}$ amendments in the six-week incubation of the calcareous soil, although this effect only persisted in the compost treatment after three-years. However, in the three-year incubation, the BC amendment exhibited a significant decrease (by 14\%) of DOC. In the acidic soil, in the six-week incubation, the DOC increased significantly in nearly all the amendments, with the exception of the BC amendment. The biggest increase was in the compost amendment, which increased by $78 \%$, followed by the increase in the compost + CA-act. BC amendment, which increased by $41 \%$. Compost + BC had the smallest significant increase (by 17\%). In the three-year incubation, only the compost and the lime amendment deviated significantly from the control, both increasing DOC by about 30\%.

In the calcareous soil, all amendments showed a DOC increase in the three-year incubation, although the control had the largest change with an increase of $115 \%$. Of the amendments, the BC and the compost $+\mathrm{BC}$ had the largest changes, $98 \%$ and $78 \%$, respectively. Similarly, in the acidic soil, all amendments showed a DOC increase in the three-year incubation, with the exception of compost and compost + CA-act. BC. Lime had the biggest DOC change, increasing by $49 \%$, whereas compost $+\mathrm{H}_{2} \mathrm{O}_{2}$-ox. BC increased the least, with $21 \%$.

\subsection{Freshly Contaminated Soils}

\subsubsection{Effects of Amendments and Incubation Time on $\mathrm{CaCl}_{2}$-Extractable $\mathrm{Cu}$}

In the six-week incubation, there was no statistically significant difference in extractable $\mathrm{Cu}$ amongst the amendments in the calcareous soil. However, after three-years, the $\mathrm{CaCl}_{2}$-extractable $\mathrm{Cu}$ showed a $25 \%$ decrease in the BC amendment and increased by $52 \%$ in the compost amendment (Figure 2a). In the acidic soil, all the amendments showed significantly decreased amounts of soluble $\mathrm{Cu}$ in the six-week incubation, with lime having the largest, with $94 \%$ (Figure 2b). However, in the three-year incubation, only lime showed a significant decrease, with $89 \%$.

(a) Calcareous Soil Freshly Spiked Cu
Amendment: $\mathrm{p}=0.017$

Incubation: $\mathrm{p}<0.001$

Amendment $x$ Incubation: n.s.

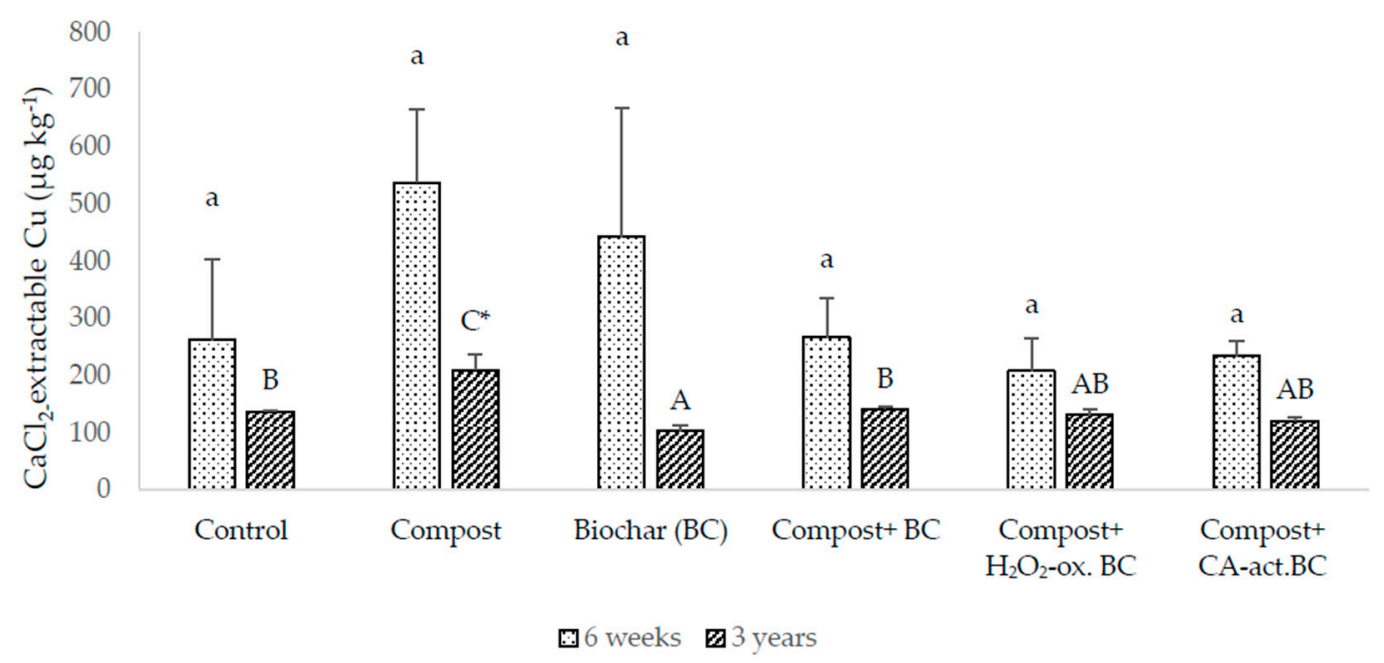

Figure 2. Cont. 
(b) Acidic Soil

Freshly Spiked Cu

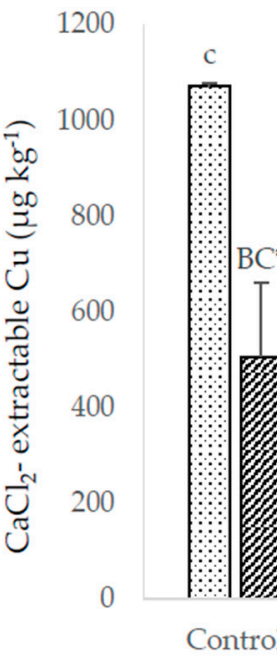

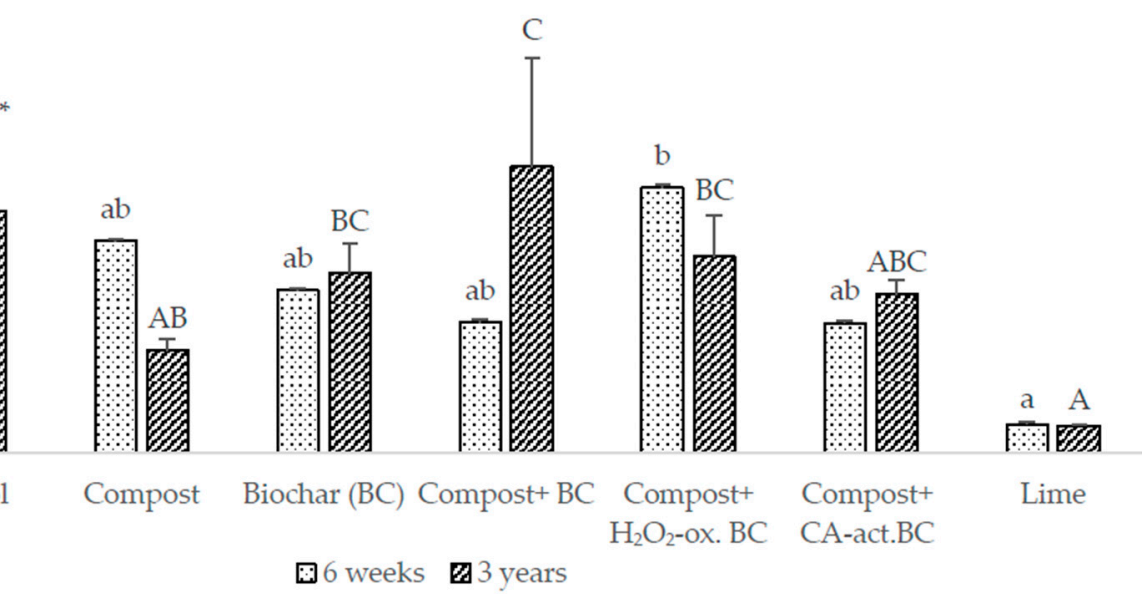

国 6 weeks 3 years
Amendment: $p<0.001$

Incubation: n.s.

Amendment $x$ Incubation: $p<0.001$

Figure 2. $0.01 \mathrm{M} \mathrm{CaCl}_{2}$-extractable $\mathrm{Cu}$ after the incubation of the amendments in freshly $\mathrm{Cu}$-spiked soils. Lowercase letters indicate significant differences between amendments after 6 weeks of incubation, uppercase letters indicate significant differences between amendments after 3 years of incubation, asterisks indicate significant differences between incubation times $(p<0.05)$. Error bars indicate standard deviation, $n=3$.

In the comparison between the six-week and three-year incubations, only compost had significantly lower concentrations of soluble $\mathrm{Cu}$ in the three-year incubation of the calcareous soil, decreasing by $74 \%$ (Figure 2a). In the acidic soil (Figure $2 \mathrm{~b}$ ), a significant $\mathrm{Cu}$ decrease was only seen for the control, while there were no significant differences between the six-week and three-year incubations for the amendments.

\subsubsection{Effects of Amendments and Incubation Time on $\mathrm{pH}$ and Extractable Organic Carbon (DOC)}

In the comparison of $\mathrm{pH}$ values in the six-week incubation of the calcareous soil, only one amendment, compost + CA-act. BC, showed a significant increase (Table 5). In the three-year incubation, there were no significant differences between the treatments, although a slightly decreasing trend in $\mathrm{pH}$ for all the amendments was observed. In the acidic soil, only lime had a significant increase in $\mathrm{pH}$ in the six-week incubation. In the three-year incubation, the compost and the lime amendments effectuated significant $\mathrm{pH}$ increases. Lime had the greatest increase, from 5.65 in the control to 6.44, whereas compost increased to 6.25 .

Table 5. $\mathrm{pH}$ and DOC concentration after the incubation of the amendments in freshly Cu-spiked soils. Lowercase letters indicate significant differences between amendments after 6 weeks of incubation, uppercase letters indicate significant differences between amendments after 3 years of incubation, asterisks indicate significant differences between incubation times $(p<0.05)$. The \pm values indicate standard deviation, $n=3$.

\begin{tabular}{|c|c|c|c|c|c|c|c|c|}
\hline & \multicolumn{4}{|c|}{$\mathrm{pH}\left(\right.$ in $\left.\mathrm{CaCl}_{2}\right)$} & \multicolumn{4}{|c|}{ DOC (mg kg-1) } \\
\hline & \multicolumn{2}{|c|}{ Calcareous } & \multicolumn{2}{|c|}{ Acidic } & \multicolumn{2}{|c|}{ Calcareous } & \multicolumn{2}{|c|}{ Acidic } \\
\hline & 6 Weeks & 3 Years & 6 Weeks & 3 Years & 6 Weeks & 3 Years & 6 Weeks & 3 Years \\
\hline Control & $6.46( \pm 0.02)$ a & $6.53( \pm 0.36) \mathrm{A}$ & $6.00( \pm 0.13) \mathrm{a}$ & $5.65( \pm 0.11) \mathrm{A}^{*}$ & $23.9( \pm 2.8)$ a & $22.3( \pm 0.7) \mathrm{A}$ & $51.4( \pm 3.9)$ a & $57.1( \pm 1.7) \mathrm{AB}$ \\
\hline Compost & $6.63( \pm 0.14) \mathrm{ab}$ & $6.48( \pm 0.06) \mathrm{A}$ & $6.29( \pm 0.13)$ a & $6.25( \pm 0.21)$ BC & $61.6( \pm 7.1) \mathrm{c}$ & $43.9( \pm 1.5) C^{*}$ & $72.0( \pm 3.4) \mathrm{a}$ & $62.3( \pm 3.0) \mathrm{AB}^{*}$ \\
\hline $\mathrm{BC}$ & $6.53( \pm 0.06)$ a & $6.15( \pm 0.19) \mathrm{A}$ & $6.26( \pm 0.20) \mathrm{a}$ & $6.05( \pm 0.12) \mathrm{ABC}$ & $24.3( \pm 1.9)$ a & $23.6( \pm 0.9) \mathrm{A}$ & $51.2( \pm 12.0)$ a & $67.5( \pm 1.1)$ B \\
\hline Compost + BC & $6.53( \pm 0.05) \mathrm{a}$ & $6.43( \pm 0.15) \mathrm{A}$ & $6.33( \pm 0.30) \mathrm{a}$ & $6.00( \pm 0.11) \mathrm{ABC}$ & $30.2( \pm 3.2) \mathrm{a}$ & $25.6( \pm 0.4) \mathrm{A}$ & $53.4( \pm 3.4)$ a & $47.9( \pm 2.2) \mathrm{A}$ \\
\hline
\end{tabular}


Table 5. Cont.

\begin{tabular}{|c|c|c|c|c|c|c|c|c|}
\hline & \multicolumn{4}{|c|}{$\mathrm{pH}\left(\right.$ in $\mathrm{CaCl}_{2}$ ) } & \multicolumn{4}{|c|}{ DOC $\left(\mathrm{mg} \mathrm{kg}^{-1}\right)$} \\
\hline & \multicolumn{2}{|c|}{ Calcareous } & \multicolumn{2}{|c|}{ Acidic } & \multicolumn{2}{|c|}{ Calcareous } & \multicolumn{2}{|c|}{ Acidic } \\
\hline & 6 Weeks & 3 Years & 6 Weeks & 3 Years & 6 Weeks & 3 Years & 6 Weeks & 3 Years \\
\hline $\begin{array}{c}\text { Compost }+ \\
\mathrm{H}_{2} \mathrm{O}_{2} \text {-ox. BC }\end{array}$ & $6.53( \pm 0.05)$ a & $6.49( \pm 0.03) \mathrm{A}$ & $6.08( \pm 0.06) \mathrm{a}$ & $6.00( \pm 0.06) \mathrm{ABC}$ & $31.4( \pm 0.9)$ a & $24.3( \pm 2.0) \mathrm{A}^{*}$ & $53.0( \pm 3.4)$ a & $68.9( \pm 15.3)$ B \\
\hline $\begin{array}{l}\text { Compost + } \\
\text { CA-act. BC }\end{array}$ & $6.79( \pm 0.09) b$ & $6.26( \pm 0.22) \mathrm{A}^{*}$ & $6.19( \pm 0.09) \mathrm{a}$ & $5.89( \pm 0.23) \mathrm{AB}$ & $45.3( \pm 7.3) \mathrm{b}$ & $31.2( \pm 2.6)$ B & $62.0( \pm 2.7)$ a & $74.4( \pm 0.9) \mathrm{BC}^{*}$ \\
\hline \multirow[t]{2}{*}{ Lime } & & & $6.85( \pm 0.12) b$ & $6.44( \pm 0.33) \mathrm{C}$ & & & $66.6( \pm 14.4)$ a & $91.1( \pm 6.6) \mathrm{C}$ \\
\hline & $\begin{array}{l}\text { Amendment: } \mathrm{n} \\
\text { Incubation: } p< \\
\text { Amendment } \mathrm{x} \\
\text { Incubation: } p=\end{array}$ & 0.001 & $\begin{array}{l}\text { Amendment: } p \\
\text { Incubation: } p< \\
\text { Amendment } \mathrm{x} \\
\text { Incubation: } \mathrm{n} \text {.s. }\end{array}$ & $\begin{array}{l}<0.001 \\
0.001\end{array}$ & $\begin{array}{l}\text { Amendment: } \\
\text { Incubation: } p \\
\text { Amendment } x \\
\text { Incubation: } p\end{array}$ & $\begin{array}{l}<0.001 \\
0.001 \\
0.001\end{array}$ & $\begin{array}{l}\text { Amendment: } \\
\text { Incubation: } p \\
\text { Amendment } \mathrm{x} \\
\text { Incubation: } p\end{array}$ & $\begin{array}{l}<0.001 \\
0.001 \\
0.001\end{array}$ \\
\hline
\end{tabular}

In the comparison of DOC in the six-week incubation period of the calcareous soil, there were significant increases in the compost and the compost + CA-act. BC amendments, by $158 \%$ and $90 \%$, respectively. In the three-year incubation, significant increases occurred again in the compost and compost + CA-act. BC amendments, increased by $97 \%$ and $40 \%$, respectively. In the acidic soil, in the six-week incubation, there were no significant differences in DOC amongst the amendments and relative to the control, although increasing tendencies were generally observed. In the three-year incubation, only lime showed a significant increase, by $60 \%$.

In the comparison of $\mathrm{pH}$ between the two incubation times of the calcareous soil, only the compost + CA-act. BC demonstrated lower values in the three-year incubation than in the six-week incubation. In the acidic soil, however, there were no significant changes from one incubation period to the other, with the exception of the control.

In the comparison of the DOC in the calcareous soil, the three-year incubation was significantly lower than in the six-week incubation for the compost, and the compost $+\mathrm{H}_{2} \mathrm{O}_{2}$-ox. BC amendments. The largest difference was again seen for the compost amendment, which decreased by $29 \%$ in the three-year incubation. In the acidic soil, there were significant differences in the compost and compost + CA-act. BC, amendments; compost had lower DOC concentrations in the three-year incubation, whereas compost $+\mathrm{CA}$-act. $\mathrm{BC}$ had increased amounts.

\section{Discussion}

In a previous greenhouse study with soil columns by Soja et al. [50], BC-based amendments produced a stronger effect in an acidic soil than in a neutral soil, and a similar result is observed here for a longer-term lab incubation study comparing historical $\mathrm{Cu}$ contamination and freshly added $\mathrm{Cu}$. In the calcareous soil, the amendments generally did not decrease $\mathrm{CaCl}_{2}$-extractable $\mathrm{Cu}$ concentrations. In fact, the compost and CA-act. BC amendments significantly increased the amount of $\mathrm{Cu}$ extracted in the historically $\mathrm{Cu}$ contaminated calcareous soil (Figure 1a). Conversely, for the acidic soil, the amendments produced a greater impact on reducing extractable $\mathrm{Cu}$ concentrations, especially in the freshly spiked treatments (Figure 2). The results suggest that it is not only the amendments themselves that may reduce metal toxicity, but notably also the effect on soil properties like $\mathrm{pH}$ associated with the application of alkaline $\mathrm{BCs}$ and lime. This is supported by a significant negative correlation between $\mathrm{pH}$ and $\mathrm{CaCl}_{2}$-extractable $\mathrm{Cu}$ in the freshly spiked treatments of the acidic soil $(r=-0.60$, $p=0.022, n=14)$. With increasing $\mathrm{pH}$, increasing negative charges and the precipitation of hydroxides, carbonates, and phosphates can influence metal sorption [35,55]. This was demonstrated for the acidic soil, where the lime amendment consistently showed the largest decrease in $\mathrm{CaCl}_{2}$-extractable $\mathrm{Cu}$. Besides the induced $\mathrm{pH}$ increase, the addition of lime could directly lead to the (surface) precipitation of $\mathrm{Cu}$-hydroxides or carbonates, further decreasing $\mathrm{Cu}$ [56].

It has been hypothesized that an increase in the soluble fraction of $\mathrm{C}$ in the soil can mobilize $\mathrm{Cu}[26,37,57]$. However, the results of this study were not as conclusive. For the calcareous soil, the effects of the amendments on $\mathrm{pH}$ were negligible, with the exception of $\mathrm{BC}$ amendment in the historically contaminated soil (Table 4). The elevated $\mathrm{pH}$ of the $\mathrm{BC}$ was accompanied by a decreased 
DOC and a decreased concentration of soluble $\mathrm{Cu}$ (Figure 1a). For the acidic soil in the historically contaminated treatments, the increase in $\mathrm{pH}$ after 6 weeks in the compost amendment was also accompanied by an increase in DOC but did not correspond to significant changes in soluble $\mathrm{Cu}$ (Figure 1b). The addition of lime resulted in an increase in both $\mathrm{pH}$ and DOC, as well as a decrease in $\mathrm{CaCl}_{2}$-extractable $\mathrm{Cu}$.

Another factor that may influence soil properties, as well as amendment effectiveness, is the duration of incubation of the amendments. In the historically contaminated soils of both sites (Table 4), the DOC levels were significantly higher in the three-year incubation than in the six-week incubation for nearly all amendments, paralleling findings by Li et al. [16] who demonstrated increasing DOC over time. It has been hypothesized that this increase in DOC is the result of the dissolution of the BCs' labile pool of organic carbon or of compost degradation [25]. The observed increase in DOC is in contrast to the $\mathrm{pH}$, which, when significant, exhibited higher levels in the six-week incubation than in the three-year incubation (Tables 4 and 5). With a decrease in $\mathrm{pH}$ and an increase in DOC in the three-year incubation, one could expect that this would correlate with an increase in soluble $\mathrm{Cu}[4,16,18,19,58]$. Instead, there was a significant decrease in $\mathrm{CaCl}_{2}$-extractable $\mathrm{Cu}$ in the three-year incubation as compared to the six-week incubation (Figure 1a,b and Figure 2a,b). This apparent contradiction in soil conditions and soluble $\mathrm{Cu}$ may be the result of the aging of the $\mathrm{BC}$ and the transformation of $\mathrm{Cu}$ to less extractable forms over time.

One defining feature of $\mathrm{BC}$ is its stability and slow degradation, leading to its extended presence in the soil $[16,27,39,59]$. As the BC is aged, it undergoes oxidation through both biotic and abiotic processes, which result in the formation of more oxygen containing surface functional groups, increasing the $\mathrm{CEC}$ and $\mathrm{Cu}$ sorption $[16,24,58]$. The observed decrease in $\mathrm{CaCl}_{2}$-extractable $\mathrm{Cu}$ (Figure 1) perhaps can be attributed to the increased oxidation of the $\mathrm{BC}$ as a result of aging. Another mechanism to consider is the aging of the $\mathrm{Cu}$. Although most metals do not undergo microbial or chemical degradation, aging may have a significant effect on $\mathrm{Cu}$ speciation. Fast processes, such as precipitation or occlusion into organic matter, may decrease the soluble $\mathrm{Cu}$ concentration rapidly after initial application, while slower reactions, such as diffusion of cations into micropores in the soil, occur over a longer time period and may further deplete bioavailable $\mathrm{Cu}$ over a longer timespan $[49,60,61]$.

A somewhat different picture was seen for the freshly $\mathrm{Cu}$-spiked soils. The extracted $\mathrm{Cu}$ levels were naturally higher after the $250 \mathrm{mg} \mathrm{kg}^{-1} \mathrm{Cu}$ spike (Figures 1 and 2); however, the spiked $\mathrm{Cu}$ was largely immobilized in both unamended soils, with $0.06 \%$ and $0.39 \%$ extractable after six weeks in the calcareous and acidic soil, respectively. The amendments did not effectuate additional $\mathrm{Cu}$ immobilization in the calcareous soil, but in the acidic soil, the soluble $\mathrm{Cu}$ was further reduced to between $25 \%$ and $50 \%$ of the unamended control by the tested organic amendments and to $6 \%$ by lime after six weeks of incubation. In the six-week incubation of the historically contaminated acidic soil, only two amendments showed significant decreases in $\mathrm{CaCl}_{2}-\mathrm{Cu}$, i.e., $\mathrm{BC}$ and lime (Figure $\mathrm{1b}$ ), while in the six-week incubation of the freshly $\mathrm{Cu}$-spiked acidic soil, all amendments showed a significant decrease in $\mathrm{CaCl}_{2}-\mathrm{Cu}$ (Figure 2b), although there were no significant changes in $\mathrm{pH}$ or DOC. This shows that the provided amendment surfaces were more effective in immobilizing freshly added $\mathrm{Cu}$ compared to historical $\mathrm{Cu}$ contamination, which was present at lower levels in the unamended control. The shorter equilibration time in freshly spiked soils compared to historically contaminated soils means that $\mathrm{Cu}$ is more mobile in the former, and thus more available for the amendments to act upon [46-49].

The three-year incubation resulted in decreased $\mathrm{CaCl}_{2}$-extractable $\mathrm{Cu}$ for only the $\mathrm{BC}$ amendment of the calcareous soil, and actually increased the amount of extractable $\mathrm{Cu}$ in the compost amendment (Figure 2a), whereas treatments of the acidic soil appeared to have little significant effect (Figure 2b). What reductions were observed were not statistically significant due to the generally higher standard deviations of soluble $\mathrm{Cu}$ in the freshly spiked treatments, indicating a larger heterogeneity of the freshly added $\mathrm{Cu}$ compared to the historical $\mathrm{Cu}$ contamination.

In the European Union, the predicted no effect concentration (PNEC) of total $\mathrm{Cu}$ in soil was set at $20-200 \mathrm{mg} \mathrm{kg}^{-1}$, with the wide range dependent on various soil properties $[5,12,50]$. Toxic effects 
on microbial and earthworm communities have been demonstrated at concentrations of $60-200 \mathrm{mg}$ $\mathrm{Cu} \mathrm{kg}^{-1}[7,9,50,62,63]$. The total $\mathrm{Cu}$ contents in the historically contaminated vineyard soils under study (201 and $337 \mathrm{mg} \mathrm{kg}^{-1}$, respectively; Table 1) were above these threshold values, and the observed reductions of soluble $\mathrm{Cu}$ effectuated by some of the tested amendments may contribute to lowering $\mathrm{Cu}$ toxicity in these soils. By contrast, in a similar study conducted by Mackie et al. [19], BC amendments did not have a significant influence on $\mathrm{Cu}$ immobilization in vineyards that had between 100 and $170 \mathrm{mg} \mathrm{Cu} \mathrm{kg}^{-1}$, and the authors suggested that perhaps the total $\mathrm{Cu}$ concentrations were simply too low for the amendments to have a more pronounced effect. A survey by Ruyters et al. [5], conducted with six Cu-impacted vineyard soils, reported that $\mathrm{Cu}$ ecotoxicity was only occasionally a problem although $\mathrm{Cu}$ concentrations were well above the limits set by the E.U. in all the studied soils. Apparently, $\mathrm{Cu}$ toxicity thresholds are very site-specific and receptor-specific as soil characteristics other than $\mathrm{Cu}$ concentration are additional important determinants of $\mathrm{Cu}$ bioavailability and the corresponding eco-toxic effects $[3,64,65]$.

\section{Summary and Conclusions}

The tested amendments had varied effects on $\mathrm{Cu}$ solubility in the studied vineyard soils. Pure compost even increased soluble $\mathrm{Cu}$, perhaps as a result of increasing DOC, while pure, non-activated $\mathrm{BC}$ was effective in immobilizing $\mathrm{Cu}$. In soils with high humus concentrations, amendment mixtures with less compost and more biochar will provide the most efficient $\mathrm{Cu}$ stabilization. In vineyard soils with deficits in soil organic carbon, the Cu-mobilizing effect of the indispensable addition of compost still could be balanced with a similarly high addition rate of biochar to benefit from its $\mathrm{Cu}$-sorption potential. The amendment with the greatest $\mathrm{Cu}$ reduction was lime in the studied acidic soil. In general, the tested amendments were more effective in immobilizing freshly added $\mathrm{Cu}$ compared to historical $\mathrm{Cu}$ contamination. However, in the historically contaminated soils, aging effects resulted in enhanced immobilization in the longer term (years) compared to the short term (weeks). The more acidic soil exhibited a stronger response to the amendments when compared to the calcareous soil, suggesting that the amendments' liming effect was an important factor for $\mathrm{Cu}$ immobilization. Our study demonstrates that for an effective reduction of soluble $\mathrm{Cu}$, particular consideration must be given to the specific soil conditions, especially the $\mathrm{pH}$ value, and the amendment type, with certain combinations, particularly with compost, potentially resulting in unwanted countereffects. This is especially important for BCs that are modified through activation processes as this incurs a higher cost. Continued research into options for remediation of $\mathrm{Cu}$-impacted soils, including their longer-term effects, will support continued soil health, especially for organic farms, which suffer from the lack of viable alternatives to $\mathrm{Cu}$-based fungicides.

Author Contributions: Conceptualization, K.M.K., G.S., and F.Z.; Methodology, K.M.K., G.S., and F.Z.; Investigation, C.P., E.S., and S.J.; Writing-Original draft preparation, C.P., E.S., and S.J.; Writing-Review and editing, K.M.K., N.J.L., G.S., and F.Z.; Visualization, C.P.; Project administration, G.S.; Funding acquisition, K.M.K., G.S., and F.Z.

Funding: This research was funded by the Austrian Ministry for Agriculture, Silviculture, Environment and Water Management (BMLFUW), research project 100888. Also, financial contributions of the provinces of Lower Austria, Styria, Burgenland and Vienna in the frame of a "Bund-Bundesländer-Kooperation" was provided, as well as the financial support by the "Winzergruppe respekt" and the Lower Austrian Winegrowers' Association.

Acknowledgments: For technical support during soil sampling and lab analyses the authors are grateful to Georg Pardeller, Bernhard Wimmer, Karin Hackl, Astrid Hobel, Ewald Brauner, and Axel Mentler.

Conflicts of Interest: The authors declare no conflict of interest. 


\section{References}

1. Wightwick, A.; Walters, R.; Allinson, G.; Reichman, S.; Menzies, N. Environmental risks of fungicides used in horticultural production systems. In Fungicides; Carisse, O., Ed.; InTech: Rijeka, Croatia, 2010; ISBN 978-953-307-266-1.

2. Dagostin, S.; Schärer, H.J.; Pertot, I.; Tamm, L. Are there alternatives to copper for controlling grapevine downy mildew in organic viticulture? Crop Prot. 2011, 30, 776-788. [CrossRef]

3. Rusjan, D. Copper in Horticulture, Fungicides for Plant and Animal Diseases. In Fungicides for Plant and Animal Diseases; Dhanasekaran, D., Ed.; InTech: Rijeka, Croatia, 2012; ISBN 978-953-307-804-5.

4. Komárek, M.; Čadková, E.; Chrastný, V.; Bordas, F.; Bollinger, J.-C. Contamination of vineyard soils with fungicides: A review of environmental and toxicological aspects. Environ. Int. 2010, 36, 138-151. [CrossRef]

5. Ruyters, S.; Salaets, P.; Oorts, K.; Smolders, E. Copper toxicity in soils under established vineyards in Europe: A survey. Sci. Total Environ. 2013, 443, 470-477. [CrossRef]

6. Wightwick, A.M.; Mollah, M.R.; Partington, D.L.; Allinson, G. Copper Fungicide Residues in Australian Vineyard Soils. J. Agric. Food Chem. 2008, 56, 2457-2464. [CrossRef]

7. Fernández-Calviño, D.; Soler-Rovira, P.; Polo, A.; Díaz-Raviña, M.; Arias-Estévez, M.; Plaza, C. Enzyme activities in vineyard soils long-term treated with copper-based fungicides. Soil Biol. Biochem. 2010, 42, 2119-2127. [CrossRef]

8. Miotto, A.; Ceretta, C.A.; Brunetto, G.; Nicoloso, F.T.; Girotto, E.; Farias, J.G.; Tiecher, T.L.; De Conti, L.; Trentin, G. Copper uptake, accumulation and physiological changes in adult grapevines in response to excess copper in soil. Plant Soil. 2014, 374, 593-610. [CrossRef]

9. Keiblinger, K.M.; Schneider, M.; Gorfer, M.; Paumann, M.; Deltedesco, E.; Berger, H.; Jochlinger, L.; Mentler, A.; Zechmeister-Boltenstern, S.; Soja, G.; et al. Assessment of $\mathrm{Cu}$ applications in two contrasting soils-effects on soil microbial activity and the fungal community structure. Ecotoxicology 2018, 27, 217-233. [CrossRef]

10. Wang, P.; Menzies, N.W.; Wang, Y.-M.; Zhou, D.-M.; Zhao, F.-J.; Kopittke, P.M. Identifying the species of copper that are toxic to plant roots in alkaline nutrient solutions. Plant Soil 2012, 361, 317-327. [CrossRef]

11. Sauvé, S.; Dumestre, A.; McBride, M.; Hendershot, W. Derivation of soil quality criteria using predicted chemical speciation of $\mathrm{Pb} 2+$ and Cu2+. Environ. Toxicol. Chem. 1998, 17, 1481-1489. [CrossRef]

12. Smolders, E.; Oorts, K.; Van Sprang, P.; Schoeters, I.; Janssen, C.R.; McGrath, S.P.; McLaughlin, M.J. Toxicity of trace metals in soil as affected by soil type and aging after contamination: Using calibrated bioavailability models to set ecological soil standards. Environ. Toxicol. Chem. 2009, 28, 1633-1642. [CrossRef]

13. Ashworth, D.J.; Alloway, B.J. Soil mobility of sewage sludge derived dissolved organic matter, copper, nickel and zinc. Environ. Pollut. 2004, 127, 137-144. [CrossRef]

14. Temminghoff, E.J.M.; Van Der Zee, S.E.A.T.M.; De Haan, F.A.M. Copper mobility in a copper-contaminated sandy soil as affected by $\mathrm{pH}$ and solid and dissolved organic matter. Environ. Sci. Technol. 1997, 31, 1109-1115. [CrossRef]

15. Römkens, P.F.A.M.; Salomons, W. Cd, $\mathrm{Cu}$ and $\mathrm{Zn}$ solubility in arable and forest soils: Consequences of land use changes for metal mobility and risk assessment. Soil Sci. 1998, 163, 859-871. [CrossRef]

16. Li, H.; Ye, X.; Geng, Z.; Zhou, H.; Guo, X.; Zhang, Y.; Zhao, H.; Wang, G. The influence of biochar type on long-term stabilization for $\mathrm{Cd}$ and $\mathrm{Cu}$ in contaminated paddy soils. J. Hazard. Mater. 2016, 304, 40-48. [CrossRef]

17. Uchimiya, M.; Chang, S.; Klasson, K.T. Screening biochars for heavy metal retention in soil: Role of oxygen functional groups. J. Hazard. Mater. 2011, 190, 432-441. [CrossRef]

18. Chaignon, V.; Sanchez-Neira, I.; Herrmann, P.; Jaillard, B.; Hinsinger, P. Copper bioavailability and extractability as related to chemical properties of contaminated soils from a vine-growing area. Environ. Pollut. 2003, 123, 229-238. [CrossRef]

19. Mackie, K.; Marhan, S.; Ditterich, F.; Schmidt, H.; Kandeler, E. The effects of biochar and compost amendments on copper immobilization and soil microorganisms in a temperate vineyard. Agric. Ecosyst. Environ. 2015, 201, 58-69. [CrossRef]

20. Uchimiya, M.; Lima, I.M.; Klasson, K.T.; Wartelle, L.H. Contaminant immobilization and nutrient release by biochar soil amendment: Roles of natural organic matter. Chemosphere 2010, 80, 935-940. [CrossRef] 
21. Karami, N.; Clemente, R.; Moreno-Jiménez, E.; Lepp, N.W.; Beesley, L. Efficiency of green waste compost and biochar soil amendments for reducing lead and copper mobility and uptake to ryegrass. J. Hazard. Mater. 2011, 191, 41-48. [CrossRef]

22. Houben, D.; Evrard, L.; Sonnet, P. Mobility, bioavailability and pH-dependent leaching of cadmium, zinc and lead in a contaminated soil amended with biochar. Chemosphere 2013, 92, 1450-1457. [CrossRef]

23. Yin, Y.; Impellitteri, C.A.; You, S.-J.; Allen, H.E. The importance of organic matter distribution and extract soil: Solution ratio on the desorption of heavy metals from soils. Sci. Total Environ. 2002, 287, 107-119. [CrossRef]

24. Borchard, N.; Prost, K.; Kautz, T.; Moeller, A.; Siemens, J. Sorption of copper (II) and sulphate to different biochars before and after composting with farmyard manure. Eur. J. Soil Sci. 2012, 63, 399-409. [CrossRef]

25. Beesley, L.; Moreno-Jiménez, E.; Gomez-Eyles, J.L. Effects of biochar and greenwaste compost amendments on mobility, bioavailability and toxicity of inorganic and organic contaminants in a multi-element polluted soil. Environ. Pollut. 2010, 158, 2282-2287. [CrossRef]

26. Park, J.H.; Choppala, G.K.; Bolan, N.S.; Chung, J.W.; Chuasavathi, T. Biochar reduces the bioavailability and phytotoxicity of heavy metals. Plant Soil 2011, 348, 439. [CrossRef]

27. Bolan, N.; Kunhikrishnan, A.; Thangarajan, R.; Kumpiene, J.; Park, J.; Makino, T.; Kirkham, M.B.; Scheckel, K. Remediation of heavy metal (loid) s contaminated soils-to mobilize or to immobilize? J. Hazard. Mater. 2014, 266, 141-166. [CrossRef]

28. Cha, J.S.; Park, S.H.; Jung, S.-C.; Ryu, C.; Jeon, J.-K.; Shin, M.-C.; Park, Y.-K. Production and utilization of biochar: A review. J. Ind. Eng. Chem. 2016, 40,1-15. [CrossRef]

29. Xu, Y.; Liu, Y.; Liu, S.; Tan, X.; Zeng, G.; Zeng, W.; Ding, Y.; Cao, W.; Zheng, B. Enhanced adsorption of methylene blue by citric acid modification of biochar derived from water hyacinth (Eichornia crassipes). Environ. Sci. Pollut. Res. 2016, 23, 23606-23618. [CrossRef]

30. Rajapaksha, A.U.; Chen, S.S.; Tsang, D.C.; Zhang, M.; Vithanage, M.; Mandal, S.; Gao, B.; Bolan, N.S.; Ok, Y.S. Engineered/designer biochar for contaminant removal/immobilization from soil and water: Potential and implication of biochar modification. Chemosphere 2016, 148, 276-291. [CrossRef]

31. Dieguez-Alonso, A.; Anca-Couce, A.; Frišták, V.; Moreno-Jiménez, E.; Bacher, M.; Bucheli, T.D.; Cimò, G.; Conte, P.; Hagemann, N.; Haller, A.; et al. Designing biochar properties through the blending of biomass feedstock with metals: Impact on oxyanions adsorption behavior. Chemosphere 2019, 214, 743-753. [CrossRef]

32. Yuan, P.; Wang, J.; Pan, Y.; Shen, B.; Wu, C. Review of biochar for the management of contaminated soil: Preparation, application and prospect. Sci. Total Environ. 2019, 659, 473-490. [CrossRef]

33. Xu, K.; Zhang, C.; Dou, X.; Ma, W.; Wang, C. Optimizing the modification of wood waste biochar via metal oxides to remove and recover phosphate from human urine. Environ. Geochem. Health 2019, 41, 1767-1776. [CrossRef] [PubMed]

34. Sohi, S.P.; Krull, E.; Lopez-Capel, E.; Bol, R. A Review of Biochar and Its Use and Function in Soil. Adv. Agron. 2010, 105, 47-82. [CrossRef]

35. Ippolito, J.A.; Laird, D.A.; Busscher, W.J. Environmental Benefits of Biochar. J. Environ. Qual. 2012, 41, 967-972. [CrossRef]

36. Singh, B.P.; Cowie, A.L. Long-term influence of biochar on native organic carbon mineralisation in a low-carbon clayey soil. Sci. Rep. 2014, 4, 3687. [CrossRef] [PubMed]

37. Wagner, A.; Kaupenjohann, M. Biochar addition enhanced growth of Dactylis glomerata L. and immobilized Zn and $\mathrm{Cd}$ but mobilized $\mathrm{Cu}$ and $\mathrm{Pb}$ on a former sewage field soil. Eur. J. Soil Sci. 2015, 66, 505-515. [CrossRef]

38. Zimmerman, A.R.; Gao, B.; Ahn, M.-Y. Positive and negative carbon mineralization priming effects among a variety of biochar-amended soils. Soil Biol. Biochem. 2011, 43, 1169-1179. [CrossRef]

39. Wang, J.; Xiong, Z.; Kuzyakov, Y. Biochar stability in soil: Meta-analysis of decomposition and priming effects. GCB Bioenergy 2016, 8, 512-523. [CrossRef]

40. Ameur, D.; Zehetner, F.; Johnen, S.; Jöchlinger, L.; Pardeller, G.; Wimmer, B.; Rosner, F.; Faber, F.; Dersch, G.; Zechmeister-Boltenstern, $\mathrm{S}$; et al. Activated biochar alters activities of carbon and nitrogen acquiring soil enzymes. Pedobiologia 2018, 69, 1-10. [CrossRef]

41. Zimmerman, A.R. Abiotic and Microbial Oxidation of Laboratory-Produced Black Carbon (Biochar). Environ. Sci. Technol. 2010, 44, 1295-1301. [CrossRef]

42. Verheijen, F.G.A.; Jeffery, S.; Bastos, A.C.; van der Velde, M.; Diafas, I. Biochar Application to Soils-A Critical Scientific Review of Effects on Soil Properties, Processes and Functions; EUR 24099 EN; Office for the Official Publications of the European Communities: Luxembourg, 2010; p. 149. 
43. Joseph, S.D.; Camps-Arbestain, M.; Lin, Y.; Munroe, P.; Chia, C.H.; Hook, J.; van Zwieten, L.; Kimber, S.; Cowie, A.; Singh, B.P.; et al. An investigation into the reactions of biochar in soil. Soil Res. 2010, 48, 501-515. [CrossRef]

44. Rechberger, M.V.; Kloss, S.; Rennhofer, H.; Tintner, J.; Watzinger, A.; Soja, G.; Lichtenegger, H.; Zehetner, F. Changes in biochar physical and chemical properties: Accelerated biochar aging in an acidic soil. Carbon 2017, 115, 209-219. [CrossRef]

45. Rechberger, M.V.; Kloss, S.; Wang, S.-L.; Lehmann, J.; Rennhofer, H.; Ottner, F.; Wriessnig, K.; Daudin, G.; Lichtenegger, H.; Soja, G.; et al. Enhanced $\mathrm{Cu}$ and $\mathrm{Cd}$ sorption after soil aging of woodchip-derived biochar: What were the driving factors? Chemosphere 2019, 2016, 463-471. [CrossRef] [PubMed]

46. Lock, K.; Janssen, C.R. Influence of aging on copper bioavailability in soils. Environ. Toxicol. Chem. 2003, 22, 1162-1166. [CrossRef] [PubMed]

47. Smolders, E.; Oorts, K.; Lombi, E.; Schoeters, I.; Ma, Y.; Zrna, S.; McLaughlin, M.J. The Availability of Copper in Soils Historically Amended with Sewage Sludge, Manure, and Compost. J. Environ. Qual. 2012, 41, 506-514. [CrossRef] [PubMed]

48. Oorts, K.; Bronckaers, H.; Smolders, E. Discrepancy of the microbial response to elevated copper between freshly spiked and long-term contaminated soils. Environ. Toxicol. Chem. 2006, 25, 845-853. [CrossRef] [PubMed]

49. Ma, Y.; Lombi, E.; Nolan, A.L.; McLaughlin, M.J. Short-term natural attenuation of copper in soils: Effects of time, temperature, and soil characteristics. Environ. Toxicol. Chem. 2006, 25, 652-658. [CrossRef]

50. Soja, G.; Wimmer, B.; Rosner, F.; Faber, F.; Dersch, G.; von Chamier, J.; Pardeller, G.; Ameur, D.; Keiblinger, K.; Zehetner, F. Compost and biochar interactions with copper immobilisation in copper-enriched vineyard soils. Appl. Geochem. 2018, 88, 40-48. [CrossRef]

51. Cross, A.; Sohi, S.P. A method for screening the relative long-term stability of biochar. GCB Bioenergy 2013, 5 , 215-220. [CrossRef]

52. Zhu, B.; Fan, T.; Zhang, D. Adsorption of copper ions from aqueous solution by citric acid modified soybean straw. J. Hazard. Mater. 2008, 153, 300-308. [CrossRef]

53. Houba, V.; Temminghoff, E.; Gaikhorst, G.; Van Vark, W. Soil analysis procedures using $0.01 \mathrm{M}$ calcium chloride as extraction reagent. Commun. Soil Sci. Plant Anal. 2000, 31, 1299-1396. [CrossRef]

54. Brandstetter, A.; Sletten, R.S.; Mentler, A.; Wenzel, W.W. Estimating dissolved organic carbon in waters by UV absorbance (254 nm). J. Plant Nutr. Soil Sci. 1996, 6, 605-607. [CrossRef]

55. Rieuwerts, J.; Thornton, I.; Farago, M.; Ashmore, M. Factors influencing metal bioavailability in soils: Preliminary investigations for the development of a critical loads approach for metals. Chem. Spec. Bioavailab. 1998, 10, 61-75. [CrossRef]

56. Brunetto, G.; de Melo, G.W.B.; Terzano, R.; Del Buono, D.; Astolfi, S.; Tomasi, N.; Pii, Y.; Mimmo, T.; Cesco, S. Copper accumulation in vineyard soils: Rhizosphere processes and agronomic practices to limit its toxicity. Chemosphere 2016, 162, 293-307. [CrossRef]

57. Beesley, L.; Dickinson, N. Carbon and trace element fluxes in the pore water of an urban soil following greenwaste compost, woody and biochar amendments, inoculated with the earthworm Lumbricus terrestris. Soil Biol. Biochem. 2011, 43, 188-196. [CrossRef]

58. Uchimiya, M.; Klasson, K.T.; Wartelle, L.H.; Lima, I.M. Influence of soil properties on heavy metal sequestration by biochar amendment: 1. Copper sorption isotherms and the release of cations. Chemosphere 2011, 82, 1431-1437. [CrossRef]

59. Ahmad, M.; Rajapaksha, A.U.; Lim, J.E.; Zhang, M.; Bolan, N.; Mohan, D.; Vithanage, M.; Lee, S.S.; Ok, Y.S. Biochar as a sorbent for contaminant management in soil and water: A review. Chemosphere 2014, 99, $19-33$. [CrossRef]

60. Lu, A.; Zhang, S.; Qin, X.; Wu, W.; Liu, H. Aging effect on the mobility and bioavailability of copper in soil. J. Environ. Sci-China 2009, 21, 173-178. [CrossRef]

61. Ma, Y.; Lombi, E.; Oliver, I.W.; Nolan, A.L.; McLaughlin, M.J. Long-term aging of copper added to soils. Environ. Sci. Technol. 2006, 40, 6310-6317. [CrossRef]

62. Jänsch, S.; Römbke, J.; Frische, T. Einsatz von Kupfer als Pflanzenschutzmittel-Wirkstoff: Ökologische Auswirkungen der Akkumulation von Kupfer im Boden; Forschungsbericht 36003040; Umweltbundesamt: Dessau, Germany, 2009; p. 72. 
63. Mackie, K.A.; Müller, T.; Kandeler, E. Remediation of copper in vineyards-A mini review. Environ. Pollut. 2012, 167, 16-26. [CrossRef]

64. Pietrzak, U.; Uren, N. Remedial options for copper-contaminated vineyard soils. Soil Res. 2011, 49, 44-55. [CrossRef]

65. Schneider, M.; Keiblinger, K.M.; Paumann, M.; Soja, G.; Mentler, A.; Golestani-Fard, A.; Retzmann, A.; Probaska, T.; Zechmeister-Bolternstern, S.; Wenzel, W.; et al. Fungicide application increased copper-bioavailaibility and impaired nitrogen fixation through reduced root nodule formation on alfafa. Ecotoxicology 2019, 28, 599-611. [CrossRef] [PubMed]

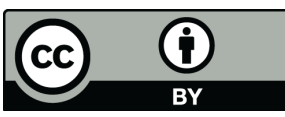

(C) 2019 by the authors. Licensee MDPI, Basel, Switzerland. This article is an open access article distributed under the terms and conditions of the Creative Commons Attribution (CC BY) license (http://creativecommons.org/licenses/by/4.0/). 